\title{
Exploring the Use of Bibliotherapy With English as a Second Language Students
}

\author{
Eliana M. Rubio Cancino ${ }^{1} \&$ Claudia P. Buitrago Cruz ${ }^{1}$ \\ ${ }^{1}$ Universidad Distrital Francisco Jose de Caldas, Faculty of Science and Education Bogota, Colombia \\ Correspondence: Claudia P. Buitrago Cruz, Universidad Distrital Francisco Jose de Caldas, Faculty of Science \\ and Education Bogota, Colombia.
}

Received: May 8, 2019 Accepted: June 15, 2019 Online Published: June 18, 2019

doi: 10.5539/elt.v12n7p98 URL: https://doi.org/10.5539/elt.v12n7p98

\begin{abstract}
Studies in trauma healing and teaching ESL students have been done before. In addition, bibliotherapy has been used in educational and psychological disciplines. However, there are few studies that explore the use of bibliotherapy and trauma healing in ESL refugee students. My objective for this study was to explore bibliotherapy to see what experiences/stories surfaced from students' lives and what connections/ reflections students made to the books we read in the bibliotherapy sessions. This was a qualitative single case study; I observed and worked with a group of ESL refugee students in an after-school program. However, for this study I followed the progress of one student over our bibliotherapy sessions. I used observations, interviews and artifacts analysis. Data was collected, triangulated and coded. I found out that the student Identified herself to some degree with the texts read during our bibliotherapy sessions. However, stories from past traumatic experiences surfaced during oral discussions but became more visible whenever she was writing.
\end{abstract}

Keywords: bibliotherapy, trauma, ESL students, refugees

\section{Introduction}

Many refugee students in Duval County, Jacksonville, Florida have experienced trauma because of their different refugee experiences. However, they are held accountable and are expected to perform as their non-refugee peers at school without considering the emotional load that these students/families carry with them. Genishi and Dyson (2009) stated "unfortunately, the climate of high-stakes testing in education and the remedial standardized curricula used to prepare children for such assessments homogenize diverse experiences" (as cited in Campano, Ghiso, \& Welch, 2016, p. 28). Teachers are concerned about their curriculum and it seems there is no exception when assessment time comes since all the students have to meet the same benchmark.

Clark-Kasimu (2015) stated when referring to refugee students, "Many of these young people have experienced intensive trauma and have legal, socio-economic, and other needs far beyond learning English, which must be met for them to advance academically" (Clark-Kasimu, 2015, p. 20). This is very true for our ESL students in Duval County. I do not know if teachers are aware of these challenges that students in their classroom are facing. However, I have not seen many teachers addressing these issues in the classroom. There is not a formalized district-wide plan or program in place to serve as an emotional support for these students.

The proposed research explored the use of bibliotherapy as a space for students to process their traumatic experiences. The purpose of this study was to see what happens when you use bibliotherapy as an approach in the classroom. Therefore, this study focused on describing what students share after reading the books I introduced to them. Tran and Hodson (2015) stated "Newcomer refugee students need all that resilience and integrity just to get through every school day" (Tran \& Hodson, 2015, p. 8). I was interested in exploring bibliotherapy, which is the use of books and other media to reconcile individuals' emotions and foster interaction among others. According to Marrs, "Bibliotherapy is the use of literature, film or other media to promote understanding and facilitate problem solving related to one's therapeutic goals" (as cited in Mumbauer, 2017, p. 86). My intent with this research was to study any possible traumatic experiences that emerge from the use of bibliotherapy.

\section{Context}

For this study, I used a small group of ESL refugee students that I work with as a volunteer tutor after school. I 
tutor for a non-profit organization in Jacksonville, FL that helps refugee students and their families in their resettlement process. Students are in grades K-12, males and females and they come from different backgrounds, therefore their educational experiences are very diverse. Even though a small group of students participated in the bibliotherapy sessions, for this research I focused on one student to study, collect and analyze the data. She is an 18-year-old female immigrant student, a senior in high school. I used the pseudonym *Andrea to protect her identity. She has three siblings and lives with her mother. Andrea came to the United States in 2015 and her father was left behind in their country of origin.

I gained access to a non-profit organization that helps refugee students by applying as a volunteer tutor. I had to fill out a form authorizing them to do a background check, then I had to go through a fingerprint process.

Participants in this "after school program" were five students who need help with homework or who need extra support in some content area concepts. This program has a regular group of students who come in the afternoons. Native languages, ethnicity, age, and gender were varied. Out of the five students, I focused this study on one participant who is an 18-year-old female in 12th grade. I conducted observations of book discussions, interviews and artifact analysis.

\subsection{Primary Research Questions}

1) What are the emerging trauma experiences surfacing from the student's stories?

2) What are the reflections/connections that students are making to the books used during bibliotherapy sessions?

\section{Theoretical Framework}

\subsection{Literature Review}

Bibliotherapy "involves selecting reading material that has relevance to the person's life situation" (Elsenman, 2016, p. 11). I considered students' background, age and reading levels when choosing the stories and books to make them relevant to their lives and appropriate for their literacy skills.

According to Cohen, "Literature can be a vehicle for students to understand and deal with issues in their own lives" (as cited in Pawan, 2002, p. 116). My intention was to bring books with which students can create a self-to-text relation. In addition, students had an opportunity to explore and express their emotions through different self-chosen activities.

\subsubsection{What Is Bibliotherapy?}

Cornet (1980) points out that bibliotherapy is the use of books to help people. However, she assumes that the reader must be personally involved with the book. Altumbay (2018) provides a more literal definition. She defines bibliotherapy as a "combination of the Greek biblion (book) and therapeia (therapy-healing)" (Altunbay, 2018, p. 201). Altumbay emphasizes that bibliotherapy is used for individuals who have emotional problems and that they need to emotionally engage and identify themselves with the texts they are reading.

\subsubsection{History of Bibliotherapy}

Cornett (1980) affirms that bibliotherapy has been used for centuries. She discusses how it has its roots in storytelling from earliest times and compares how Aristotle and other roman orators used stories to "heal emotions". In contrast, Altumbay (2018) states that the history of bibliotherapy is more recent and that it appeared as a response to World War I. According to Altumbay, bibliotherapy was used as an alternative method to treat people who struggle after the war with the economic, social and political depression after the war.

\subsubsection{Stages of Bibliotherapy}

Eisenman (2016) identifies four stages of bibliotherapy: Identification, catharsis, insight and universalization. The first one corresponds to a student identifying himself or herself to the text that they are reading. The second stage, catharsis, focuses on a "release" of emotions after following a character. The "insight" stage is more of a "connection" between the text and the reader. Finally, universalization is the stage in which the reader realizes that people around the world have similar problems.

\subsubsection{Methodology of Bibliotherapy}

Cornett (1980) identifies preparation and implementation steps for conducting a session of bibliotherapy. The first steps are: identifying students/ participants, match students with appropriate texts, determine setting and activities. Once the preparation stage is completed, then implementation steps must be put into practice, which includes: motivate students, provide reading, allow "incubation time" (Cornett, 1980, p. 20), provide follow up and closure. 


\subsubsection{Rationale for Bibliotherapy}

Bibliotherapy is a non-threatening way to help children deal with emotional issues. According to Cianciolo (1965), "Fiction can affect the coping behavior of children. A counselor may effectively involve the child with an emotional and psychological attachment to a literacy character" (as cited in Watson, 1980, p. 205). Most importantly, bibliotherapy creates a connection between the reader and the student. Berg-Cross (1976) points out that bibliotherapy "provides the therapist and the child with a shared experience and the basis for trust and developing a friendship" (Berg-Cross, 1976, p. 35). Creating a connection with a student as well as creating a text-to-self connection is especially important for students dealing with traumatic experiences. Although the benefits for bibliotherapy are numerous Cornett (1980) warns the reader that bibliotherapy might hurt the child if the wrong book is used at the wrong time.

\subsubsection{Trauma}

According to Fuertes, "There are millions of war survivors, and many have become refugees, needing to get through their trauma so that they can recover and start rebuilding their lives and community" (Fuertes, 2004, p. 491). There are many sources of trauma, few considered in this study are: displacement from native country, lack of socio-economical resources, domestic violence and family separation in the process of relocating to the United States.

The Center for Suicide Prevention (2018), states that some examples of traumatic experiences are losing a loved one and childhood abuse or neglect. These experiences cause some effects such as suicide attempts; and relationship problems. Some symptoms of trauma include aggressive behaviors, memories, flashbacks, and/or nightmares of the traumatic event.

Van der Kolk describes the nature of trauma, stating that "traumatization occurs when both internal and external resources and inadequate to cope with external threat" (as cited in Bloom, 1999, p. 1). In addition, Van der Kolk asserts that it is not the traumatic event that causes the damage but the way the body and the mind react to this event.

Although trauma has been studied by researchers in the fields of psychology and counseling, few studies have used trauma as a perspective in education. According to Dutro and Bien (2014), "The trauma studies scholarship on which we draw offers lenses that have not yet been centrally applied to questions in education, though it resonates deeply with related critical theoretical arguments surrounding student experience and opportunity in schools" (p. 12). The nature of my case study was not clinical, as it did not intend to "treat" and it did not seek to "heal". Instead, this research aimed to look at relationships, connections and emerging trauma experiences surfacing from the student's stories.

According to Caruth, trauma has an amnesic quality and is unspeakable (as cited in Pederson, 2014, p. 334). From this perspective trauma is so painful that the brain cannot process the events normally and when memories come back, the person is unable to describe them in words. However, Caruth states that imaginative literature and fiction help individuals speak about their trauma. Pederson (2014) uses a relevant analogy to explain Caruth's perspective of trauma: while the physiological senses keep recording (smell, sound, etc.) the videographer leaves, but the tape keeps running.

On the other hand, Richard McNally released a review called "Remembering Trauma" (2003), in which he challenged Caruth's theory. According to McNally's studies, traumatic amnesia is a myth. He claims that individuals do remember their traumatic experiences but choose not to talk about them. "For McNally, unlike for Caruth, trauma is memorable and describable" (as cited in Pederson, 2014, p. 334). These new studies challenge the concept that trauma as an "unrepresentable" event that individuals' brain did not process correctly and is forgotten.

Pederson (2014) offers an alternative framework called Literacy Trauma Theory. This framework is grounded in the principles that traumatic memories are both memorable and speakable, and that talking about the traumatic event helps in the process of rehabilitation. Traumatic events are uncommon; consequently, they are more powerful which can lead to more lively details in their descriptions. 


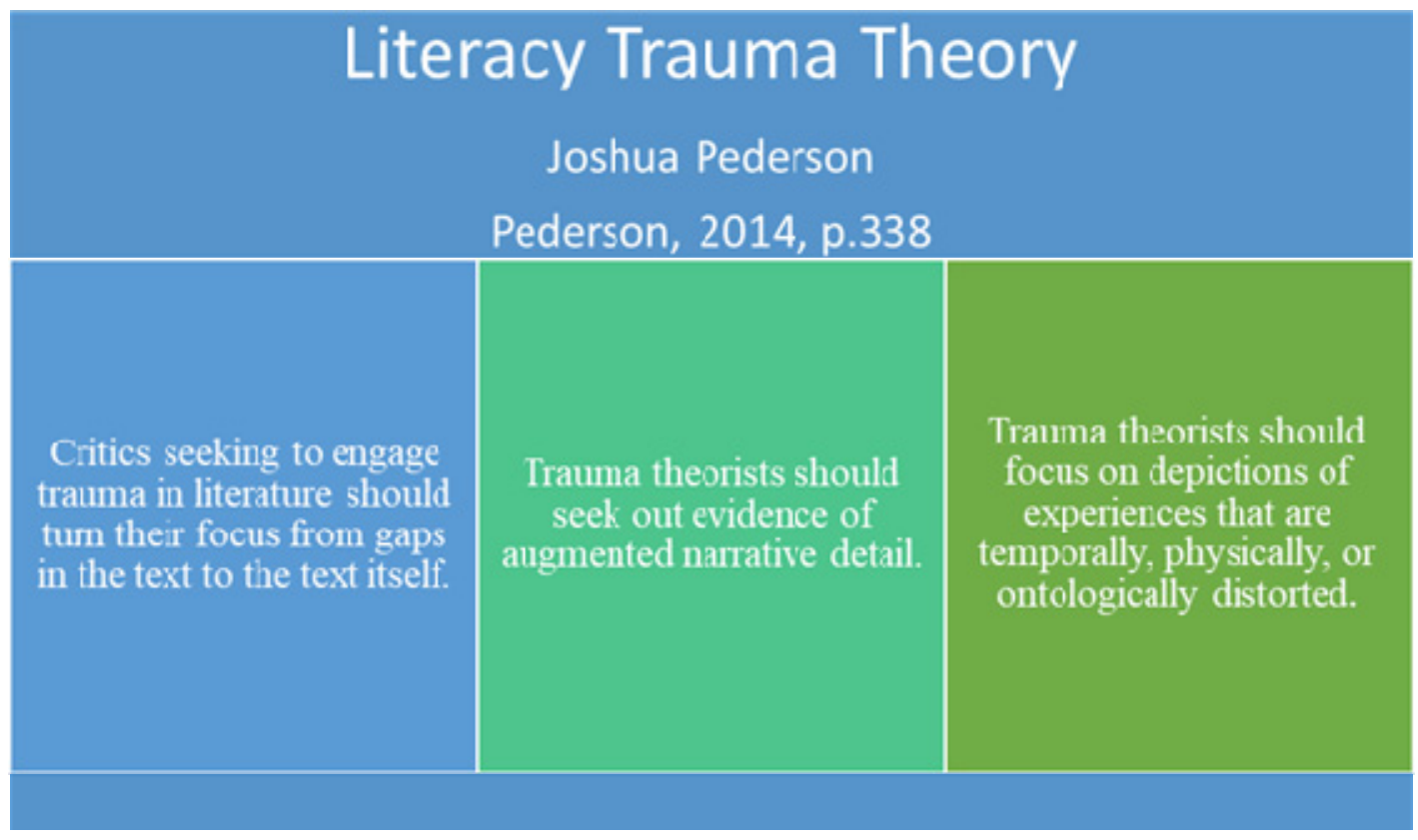

\section{Methodology}

For this study, I used the qualitative method because I was looking for an understanding of the use bibliotherapy and student's traumatic experiences. Additionally, I was looking for both anticipated and unanticipated factors contributing to trauma. Braun and Clarke (2013), distinguish qualitative and quantitative research by stating that "the most basic definition of qualitative research is that it uses words as data...collected and analyzed in all sorts of ways, quantitative research, in contrast uses numbers as data and analyzes them using statistical techniques" (as cited in Merriam \& Tisdell, 2016, p. 6). In this study, I was not examining numbers or using statistics. I was observing, interviewing and analyzing students' work to see instances of trauma that emerged during students' bibliotherapy sessions.

Most importantly, I was using a qualitative case study method. According to Merriam and Tisdel (2016) in qualitative case studies "the researcher as the primary instrument of data collection and analysis, an inductive investigative strategy and the end product being richly descriptive" (p. 37). In this particular study, I was observing and describing any possible traumatic experiences that emerged when exploring bibliotherapy.

\subsection{Data Collection}

I brought in different books/articles for students twice a week. Students chose which text they wanted me to read to them and sometimes I read aloud, or we read together. We engaged in a reflective discussion and did a student-chosen activity, either written or pictorial (drawing/painting), after we read each book. These bibliotherapy sessions were not considered therapeutic treatment; they were just a safe space for students to deal with a present or past issue in their lives. After reading the book chosen by the students, I invited them to share their reflections and connections in their chosen "mode". Students could elect to draw, paint or write.

I used a semi-structured protocol to interview Andrea twice during this case study. These interviews were intended to understand what traumatic experiences surfaced from her life (Appendix A). Each interview lasted from 30-35 minutes and they were recorded using a Surface device, then they were transcribed using the Temi software.

During the bibliotherapy sessions, students wrote, drew and created artifacts about their lives in order to explore any traumatic experiences. For example, after reading Persepolis 1 students created the "About Me Book" (Appendix B). In this activity, students could write about the things that made them happy, sad, their hobbies, their family and friends. These artifacts were collected, scanned and analyzed. Although I collected all students' artifacts, I focused on Andrea's artifacts for the analysis of this case study.

In addition, two observations of the bibliotherapy discussions were conducted and recorded using a video-audio recording device. These observations intended to search for any traumatic experiences that emerged from Andrea's life during our discussions (see Appendix $\mathrm{C}$ an example of questions used during one of the 
bibliotherapy sessions).

According to Merriam and Tisdell (2016), "Data collection and analysis begins with the first interview, the first observation, the first document read" (p. 191). The analysis of the data in this qualitative study required a close relation between me (researcher), the participants, the data triangulation and my interpretations/descriptions.

The data analysis in this study focused on identifying emerging trauma experiences surfacing from students and the reflections/connections that students made to the books used during bibliotherapy sessions. Nevertheless, this study did not measure the effectiveness of bibliotherapy.

\subsection{Interviews}

I used the audio recording device to record the interviews with students in the program. Merriam and Tisdell (2016) stated, "In education, if not in most applied fields, interviewing is probably the most common form of data collection in qualitative studies. In some studies, it is the only source of data" (p. 106). I chose interviewing because this is a qualitative study and through it, I wanted to understand how students perceived traumatic past and present events.

I attempted to include paralinguistic features (e.g. crying), pauses, gaps and gestures if they were present during the interview. I used one of the Temi transcription software to transcribe my interview.

\subsection{Artifacts}

Artifacts were analyzed to identify trauma experiences that emerged from students' work. I analyzed students' work such as journal entries, art work and written representations created by students. To analyze these artifacts, I scanned them into a PDF and/or PNG file to manipulate and improve image resolution.

\subsection{Observations}

I used a video-audio recording device to observe the different trauma experiences emerging from students during the book discussions. According to Paulus, Lester and Dempster (2014), "Video recording allows you to analyze non-verbal communication such as gesture and eye gaze or provide insights into the ways participants use artifacts in their everyday interactions" (p. 147). I used video recording to observe possible trauma factors that arose from the reflective

\section{Results}

\section{*Andrea}

Andrea came to the United States in 2015. She is a senior in high-school and she is 18 years old. She lives with her mom and siblings because her father stayed back in their home country while the mother immigrated to the US to give her children better educational opportunities. Mother lives off her income as a secretary and strives to raise her three children by herself on that income.

On the other hand, Andrea has been diagnosed with Obsessive Compulsive Disorder (OCDM) at school. She takes medication and school recommended psychotherapy for her once a week. However, due to financial constrains she is only seeing her psychiatrist once a month if there is enough money to cover the appointment.

After coding the data from the bibliotherapy sessions and triangulating the results, the following main themes were identified: Finances, mental health and relationships.

\begin{tabular}{lll}
\hline Main Theme & Sub-Theme & Data Extract \\
\hline Finances & $\begin{array}{l}\text { Financial } \\
\text { Struggles }\end{array}$ & $\begin{array}{l}\text { "My mother supports three children and has minimum amount of } \\
\text { support financially from her family". } \\
\text { "My sister is a sophomore in college and my brother will attend } \\
\text { college in three years, this is a huge educational financial } \\
\text { responsibility for my mother to carry on her shoulders financially". } \\
\text { "Will I have mental help support? } \\
\text { "I learned that I was struggling with Obsessive Compulsive } \\
\text { Disorder. At first, I did not want to accept that diagnosis. With the } \\
\text { help of medicine and therapy, I have slowly learned to accept this is } \\
\text { who I am". } \\
\text { "During our move, my family and I learned more about ourselves, }\end{array}$ \\
& &
\end{tabular}


we grew together as a family and I discovered something about myself".

Suicide "One of my siblings wanted to hang themselves"

Attempts

"I remember staying outside forcing myself to stay in the cold and running away"

Leaving her "Bits and pieces of my childhood and teenage memories compacted Home country into two suitcases, ready to be shipped out of their own country. Our suitcases just shoved in the trunk and closed with so many precious memories from our past".

"The four of us moved into a house, in Hopkinton, New Hampshire, which we shared with two other families. The house looked doubtful on the outside. We arrived, and our rooms were empty of furniture. The atmosphere of the house matched how my family and I felt that night".

Relationships Family Separation
"My dad taught me how to repair electronics and computers and to repair other miscellaneous objects around the house like the broken vacuum cleaner and other electronics. He taught us that appliances should not be thrown out because it is bad for the environment. He taught us to be repairmen in order to help my mother when he was not there. When we moved to the United States without my father, the plan was for us to be able to fix the appliances and help my mother in case of emergency in my dad's absence!"

Struggles with "I don't have any friends, I just want one person to like me, to be my friendships friend"

"My family and I love spending time together. We enjoy walking together outside, and have fun together playing board games"

\subsection{Finances}

Family struggles financially. Andrea has three siblings and a single mom that provides the only income for the household. Visits to the psychiatrist for Andrea are sporadic and based on available resources and expenses every month. She wants to attend college, but the financial circumstances are limiting Andrea's options for higher education.

\subsection{Mental Health}

Andrea has been diagnosed with Obsessive Compulsive Disorder. She stated that "thoughts would run through her head and she could not stop them". She and her siblings have attempted to commit suicide. As she expressed during the interview, she has experienced trauma at the hands of her father. She is currently taking medication for her OCD and receives psychotherapy on inconsistent basis.

\subsection{Relationships}

Andrea struggles making friends; she says "I don't have any friends, I just want one person to like me, to be my friend". In her writing she expresses that she feels lonely and her friends were left behind in her home country. Other students in the group do not like her because "she is weird". However, Andrea has a person in the group that advocates for her and informs teachers when Andrea is not doing well emotionally. For example, she told me that Andrea was "cutting her eyelashes, because they were on her way when swimming" and that she saw Andrea "cutting herself". These observations were helpful for me and teachers/staff to keep a close eye on Andrea and to get her the emotional support she needed.

\section{Discusion}

Some of the emerging trauma experiences that surfaced during the bibliotherapy sessions were history of abuse and suicidal attempts.

During our interviews, Andrea disclosed that her dad yells, name calls, becomes intimidating and has become physical. According to her, the last altercation occurred a year ago when he visited them. He became upset with 
her, pushed her to the ground and attempted to punch her in the face. Andrea moved, and he missed, hitting her leg. She also said that the intimidation was worse when she was younger and that she fears her father because he is "unpredictable" and he "yells". However, she states that she wants to help others overcome challenges.

Andrea likes to write more than she likes to talk about past traumatic issues. In her writing, she tells the story of how she attempted to commit suicide by running away in the cold and freezing to death. Few excerpts from her journal evidence the way she was organizing her writing and her recollection of the events. Andrea also disclosed that there is history of suicidal attempts among her family.

During one of our bibliotherapy sessions, we read an article about Allison Schmitt. I picked this article because I knew Andrea likes swimming. After reading and talking about the challenges Allison Schmitt faced in her life Andrea wrote:

"I am impressed by Allison Schmitt, she suffered from depression and similarly to me, she used swimming as a tool to cope her depression. Allison is a brave woman that overcame so many obstacles through her life. Her journey is similar to mine, she did not want to reach out for help but with the help of others, she helped herself and now loves helping others. Allison explains that in life, "it's ok to not be ok". Allison Schmitt is kind and compassionate and always loves helping people. Through hard times, she persevered in her professional and swimming career."

This is one of the times I have seen her directly connecting to the text. Other times, she does not identify with the characters of the stories but with the events themselves. For example, when reading a chapter of the graphic novel Persepolis 1, Andrea identified her personal immigration story with the main character's immigration story and she wrote:

"We were about to be shipped to the United States. It was hard leaving our country with bits and pieces of my childhood and teenage memories compacted into two suitcases, ready to be shipped out of their own country. Our suitcases just shoved in the trunk and closed with so many precious memories from our past".

The data collected during the bibliotherapy sessions supports McNally's theory that "trauma is memorable and describable" (as cited in Pederson, 2014, p. 334). Andrea was able to recall past traumatic events and write about them. In fact, she was more detailed and descriptive when writing her narratives than with speaking about these episodes. This aligns to McNally's statement regarding traumatic experiences and individuals' recollection of events; "[E]motional stress enhances memory for the central features of the stressful experience. Stress does not impair memory; it strengthens it" (as cited in Pederson, 2014, p. 339). In this study, I observed that traumatic experiences are retrievable and are more describable than regular events.

After doing our bibliotherapy sessions, I asked Andrea to pick a book for me to send it to her the last day before the break, she was absent because she was sick. I received this email the day after.

Hello,

I just received my book today and I wanted to thank you so much for all the help you have provided !! It means so much to me and I'm so glad you are apart of my life. You are my friend and I'm so happy really really happy! I feel so much more comfortable with you this year and I can't wait to know you more!

I'm sorry I didn't come by today, I wanted to but I felt horrible, I am sick and have a cold. I was sneezing all day and was dizzy... I think I will first get over it and then see you 'cause I don't want to get you sick, if I come I know you will get the virus so I will stay away until I'm back!

Thank you so much again!

As an educator, exploring bibliotherapy has been a way to connect to my students and to be more aware of the emotional challenges that they bring to school every day. It has served as a bridge to understand students' past experiences in a non-threatening way. This study did not intend to "treat" but instead it was more of an experimentation to use bibliotherapy and see what themes/ connections and past traumatic experiences surfaced.

\section{Conclusions}

Research in trauma has two conflicting theories regarding how trauma is processed and recalled by the human brain. Caruth states that trauma has an "amnesic quality and is unspeakable" (as cited in Pederson, 2014, p. 334). However, McNally (2007) claims that individuals do remember their traumatic experiences but choose not to talk about them. On the other hand, Pederson (2014) proposes a Literacy Trauma Theory, from his perspective traumatic memories are both memorable and speakable, talking about the traumatic experience can be beneficial for rehabilitation and traumatic events are more powerful in the memory, which can lead to more details in their descriptions when writing or talking. 
Based on the results, past traumatic experiences from Andrea's life surfaced during the bibliotherapy sessions. Experiences of domestic violence, suicidal attempts and moving to another country were evident. The themes identified were finances, mental health and relationships. Andrea's recollection of events was memorable and detailed, which supports McNally's (2007) trauma theory and Pederson's (2014) stance regarding detailed recollection and description of traumatic events.

\section{References}

Altunbay, M. (2018). Using literature in bibliotherapy: Biography sampling. Journal of Education and Training Studies, 6(11), 201-206. https://doi.org/10.11114/jets.v6i11.3593

Archuleta, A. J., \& Lakhwani, M. (2016). Posttraumatic stress disorder symptoms among first-generation Latino youths in an English as a second language school. Children \& Schools, 38(2), 119-127. https://doi.org/10.1093/cs/cdw005

Bloom, S. (1999). Trauma Theory Abbreviated. A coordinated Community Response to Family Violence. Commonwealth of Pennsylvania, 1-17.

Berg-Cross, G., \& Berg-Cross, L. (1976). Bibliotherapy for young children. Journal of Clinical Child Psychology, 5(2), 35. https://doi.org/10.1080/15374417609532709

Campano, G., Ghiso, M., \& Welch, B. (2016). Partnering with immigrant communities: Action through literacy. New York: Teachers College Press.

Clark-Kasimu, N. (2015). Serving refugee students and unaccompanied minors: More than just learning English. Voices in Urban Education, 41, 20-25.

Cornett, C. E., \& Cornett, C. F. (1980). Bibliotherapy: The right book at the right time. Phi Delta Kappa Intl Inc, $8-40$.

Dutro, E., \& Bien, A. C. (2014). Listening to the speaking wound: A trauma studies perspective on student positioning in schools. American Educational Research Journal, 51(1), 7-35. https://doi.org/10.3102/ 0002831213503181

Elley, S. (2014). Examining the use of bibliotherapy in a third-grade classroom. Texas Journal of Literacy Education, 2(2), 91-97.

Elsenman, G., \& Harper, R. (2016). Bibliotherapy for classroom management. Dimensions of Early Childhood, 44(1), 11-17.

Fuertes, A. B. (2004). In their own words: Contextualizing the discourse of (war) trauma and healing. Conflict Resolution Quarterly, 21(4), 491-501. https://doi.org/10.1002/crq.77

Gómez, J. M. (2018). What's the harm? Internalized prejudice and cultural betrayal trauma in ethnic minorities. American Journal of Orthopsychiatry, 1-11.

Karabenick, S. A., \& Noda, P. A. (2004). Professional development implications of teachers' beliefs and attitudes toward English language learners. Bilingual Research Journal, 28(1), 55-75. https://doi.org/ $10.1080 / 15235882.2004 .10162612$

McNally, R. J. (2007). Betrayal trauma theory: A critical appraisal. Memory, 15(3), 280-294. https://doi.org/10.1080/09658210701256506

Merriam, S. B., \& Tisdell, E. J. (2016). Qualitative Research: A Guide to Design and Implementation (4th ed.). San Francisco, CA: Jossey-Bass.

Mumbauer, J., \& Kelchner, V. (2017). Promoting mental health literacy through bibliotherapy in school-based settings. Professional School Counseling, 21(1), 85-92. https://doi.org/10.5330/1096-2409-21.1.85

Olivos, E. M., \& Sobko, S. (2017). Cuentos para dormir: Bedtime stories by deported parents. Bilingual Review, 33(5), 117-136.

Paulus, T. M., Lester, J. N., \& Dempster, P. (2014). Digital tools for qualitative research. London, UK: Sage. https://doi.org/10.4135/9781473957671

Pawan, F. \& Pugh, S. L. (2002). Reading for life. In G. Crosling, \& G. Webb (Eds.), Supporting students learning (pp. 111-118). London: Kogan Page Publishers.

Pederson, J. (2014). Speak, trauma: Toward a revised understanding of literary trauma theory. Narrative, 22(3), 333-353. https://doi.org/10.1353/nar.2014.0018 
Piers, C. (1998). Contemporary trauma theory and its relation to character. Psychoanalytic Psychology, 15(1), 14-33. https://doi.org/10.1037/0736-9735.15.1.14

Pola, A., \& Nelson, R. (2014). The impact of bibliotherapy on positive coping in children who have experienced disaster. Therapeutic Recreation Journal, 48(4), 341-344.

Radstone, S. (2007). Trauma theory: Contexts, politics, ethics. Paragraph: A Journal of Modern Critical Theory, 30(1), 9-29. https://doi.org/10.3366/prg.2007.0015

The Center for Suicide Prevention. (2018) Trauma and suicide. Retrieved from https://www.suicideinfo.ca/resource/trauma-and-suicide/

Tran, D., \& Hodgson, B. R. (2015). Meeting the needs of refugee and immigrant students and families in a culturally responsive way. Voices in Urban Education, 41, 7-15.

Watson, J. (1980). Bibliotherapy for abused children. School Counselor, 27, 204-208.

\section{Appendix A}

\section{Interview Questions}

\section{Student Interview Questions set \#1}

- How do you like your school?

- What is the best part of school?

- What bothers you the most about school?

- Do you prefer working in groups or by yourself? Why?

- What are your favorite hobbies?

\section{Student Interview Questions set \#2}

- How was your move from your home country to the United States?

- Tell me about your family.

- How would you change your family if you could?

- What makes you happy?

- What makes you sad?

\section{Appendix B}

\section{About Me Book (Cornett, 1980, p.22)}

Students can choose to draw, write, and/or create an "About Me Book". They can "tell” their story like Marji did in Persepolis or they can write about the things that makes them happy, sad, their hobbies, their family and friends.

\section{Appendix C}

\section{Discussion Sequence Protocol: "Persepolis 1"}

- What is this story about?

- How would you tell your life story? How would you write those events?

- What are Marji's problems?

- How do you think she felt?

- How has Marji's life change?

\section{Copyrights}

Copyright for this article is retained by the author(s), with first publication rights granted to the journal.

This is an open-access article distributed under the terms and conditions of the Creative Commons Attribution license (http://creativecommons.org/licenses/by/4.0/). 